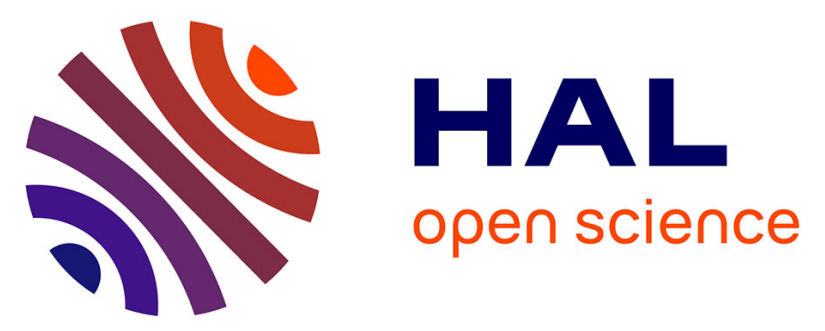

\title{
Towards the Use of Biochemical Indicators in the Raw Fruit for Improved Texture of Pasteurized Apricots
} Albert Ribas, Barbara Gouble, Sylvie Bureau, Jean Francois Maingonnat, Jean Marc Audergon, Catherine M.G.C. Renard

\section{To cite this version:}

Albert Ribas, Barbara Gouble, Sylvie Bureau, Jean Francois Maingonnat, Jean Marc Audergon, et al.. Towards the Use of Biochemical Indicators in the Raw Fruit for Improved Texture of Pasteurized Apricots. Food and Bioprocess Technology, 2017, 10 (4), pp.1-12. 10.1007/s11947-016-1850-7 . hal01424786

\author{
HAL Id: hal-01424786 \\ https://hal.science/hal-01424786
}

Submitted on 2 Jan 2017

HAL is a multi-disciplinary open access archive for the deposit and dissemination of scientific research documents, whether they are published or not. The documents may come from teaching and research institutions in France or abroad, or from public or private research centers.
L'archive ouverte pluridisciplinaire HAL, est destinée au dépôt et à la diffusion de documents scientifiques de niveau recherche, publiés ou non, émanant des établissements d'enseignement et de recherche français ou étrangers, des laboratoires publics ou privés. 


\title{
Towards the Use of Biochemical Indicators in the Raw Fruit for Improved Texture of Pasteurized Apricots
}

\author{
Albert Ribas-Agustí $^{1,2}$ (D) Barbara Gouble ${ }^{1} \cdot$ Sylvie Bureau $^{1}$. \\ Jean-François Maingonnat ${ }^{1} \cdot$ Jean-Marc Audergon $^{3}$ - Catherine M. G. C. Renard $^{1}$
}

Received: 30 August 2016/Accepted: 12 December 2016

(C) Springer Science+Business Media New York 2016

\begin{abstract}
Quality of canned apricots is seriously compromised by the loss of their flesh firmness during pasteurization. This work conducted a comprehensive characterization of the biochemical properties of raw apricots, as well as of the tissue softening during pasteurization using a multimethodology approach. Biochemical and textural results were analyzed to seek possible correlations, with the aim to elucidate which properties could be used as indicators in raw fruit for obtaining pasteurized products with better texture. There were large effects of cultivar, ripening stage, and intra-fruit zone on the biochemical and textural properties of apricots. The titratable acidity, amongst ethylene production, soluble solid content, and pectinolytic enzyme activities, was the biochemical property that correlated more robustly to the loss of texture. It had significant correlation coefficients of -0.9 and 0.5 with firmness of pasteurized fruit and loss of firmness, respectively. We propose titratable acidity to be used as indicator for raw material selection and/or to be modulated during apricot food processing.
\end{abstract}

Keywords Biochemical properties · Canning · Firmness · Pectinolytic enzymes $\cdot$ Thermal treatment $\cdot$ Titratable acidity

Albert Ribas-Agustí

albert.ribas-agusti@outlook.es

1 UMR408 SQPOV Sécurité et Qualité des Produits d'Origine Végétale, INRA, University of Avignon, 84000 Avignon, France

2 Present address: Department of Food Technology, University of Lleida, Rovira Roure 191, 25198 Lleida, Spain

3 UR1052 GAFL Unité de Génétique et d'Amélioration des Fruits et Légumes, INRA, 84000 Avignon, France

$\begin{array}{ll}\text { Abbreviations } \\ \alpha \text {-Arab } & \alpha \text {-Arabinosidase } \\ \beta \text {-Gal } & \beta \text {-Galactosidase } \\ \text { EE } & \text { External equatorial } \\ \text { EP } & \text { External pistil } \\ \text { G } & \text { Goldrich } \\ \text { H } & \text { Hargrand } \\ \text { I } & \text { Iranien } \\ \text { ME } & \text { Median equatorial } \\ \text { MP } & \text { Median pistil } \\ \text { M1 } & \text { Commercial harvest } \\ \text { M2 } & \text { Half-ripe } \\ \text { O } & \text { Orangered } \\ \text { PCA } & \text { Principal component analysis } \\ \text { PG } & \text { Polygalacturonase } \\ \text { PME } & \text { Pectinmethylesterase } \\ \text { SSC } & \text { Soluble solids content } \\ \text { TA } & \text { Titratable acidity }\end{array}$

\section{Introduction}

Texture is one of the attributes which contributes the most to quality of apricot (Prunus armeniaca L.) products, and it is paramount for consumer acceptance. However, apricots are prone to severe texture loss, which is aggravated when they are subjected to thermal processing (Mallidis and Katsaboxakis 2002). The firmness of fruit and vegetable tissues is determined, to a great extent, by the chemical properties of cell walls (Van Buren 1979). The plant cell wall is an interactive assembly of polysaccharides mainly consisting of pectin, cellulose, and hemicelluloses. Amongst them, pectin has a key involvement in the mechanical strength of cell walls and in the adhesion between cells. Thus, changes in pectin structure induce, inevitably, changes in texture (Van Buggenhout et al. 
2009). Pectin evolves with the fruit maturation, triggered by the hormone ethylene, which regulates the main physiological changes of climacteric fruit (Brummell et al. 2004). Molecular weight, degree of methoxylation, and neutral sugar compositions of side chains of the pectic polymers all influence cell wall texture (Billy et al. 2008; Ella Missang et al. 2012). These chemical properties can be modified by pectinolytic enzymes, such as pectinmethylesterase (PME, E.C. 3.1.1.11), which catalyzes the de-esterification of the methyl groups; polygalacturonase (PG, E.C. 3.2.1.15), which catalyzes the depolymerization of the unesterified pectic polymers; and the glycosidases $\beta$-galactopyranosidase ( $\beta$-galactosidase $(\beta$-Gal), E.C. 3.2.1.23) and $\alpha$-arabinofuranosidase ( $\alpha$-arabinosidase ( $\alpha$-Arab), E.C. 3.2.1.55), which catalyze the cleavage of the glycosidic side chains of pectins (Duvetter et al. 2009). These modifications lead to pectin depolymerization and solubilization, which are correlated with a decrease in the fruit firmness (Brummell et al. 2004; Ella Missang et al. 2012).

Tissue softening due to pectin modifications and solubilization is also non-enzymatically induced by heating. Firmness has been associated with the chelator-soluble pectin (CSP), i.e., those pectic polymers that are bound to the rest of the cell wall through ionic bridges (Chen et al. 2013). The CSP is precisely the apricot pectin fraction most susceptible to chemical changes during thermal treatment (Ella Missang et al. 2012). How pectin is depolymerized at high temperature depends on $\mathrm{pH}$ : at $\mathrm{pH}$ above 5 , pectin is degraded by $\beta$ elimination and the degradation is more pronounced if the pectin has a high degree of methoxylation (Diaz et al. 2007; Van Buggenhout et al. 2009). At low pH, pectin is degraded by acid hydrolysis, and the degradation accelerates as the degree of methoxylation decreases (Fraeye et al. 2007).

Historically, it has been difficult to deal with the texture of cooked apricots. Early works report confusing effects of several factors such as acidity of the variety, advanced maturity, excessive cooking, or presence of pectinolytic enzymes due to fungal contamination (Claypool 1974; Sommer et al. 1977). The apparently erratic behavior of the apricot texture upon thermal treatment and the difficulty to manage it in the food industry have lead to nonconformance of part of the production or disaffection of the consumers due to excessive softness of the product. Food industry has made efforts since long time ago to overcome these problems. Once the fungal contamination issues were controlled (Sommer et al. 1977), there still remain factors intrinsic to the raw fruit. Often, the producers select apricots that have been harvested at early stages of their ripening. This helps to ensure the texture of the final product, but it is detrimental for its taste and flavoring properties (Botondi et al. 2003). Furthermore, Ella Missang et al. (2011) found that the firmness of the raw apricots only partially explained the firmness of the cooked fruit, while other factors such as cultivar and intra-fruit zone had more correlation with the loss of texture than initial firmness.
It would be of special interest to identify the raw fruit properties with the highest correlation with the texture changes in pasteurized apricots and use them as technological indicators for selection of the raw fruit. In this work, we aimed to do such identification, by measuring several biochemical properties of apricot with potential influence on the chemical structure of pectin. We chose apricots belonging to different categories of those factors that may affect the pectin structure: cultivar, ripening stage, and intra-fruit zone. The aim was to obtain variability in order to correlate, as best as possible, the different biochemical properties with texture loss. In the pursuit of this objective, we made a comprehensive characterization of the texture changes of pasteurized apricots, using different methodologies. The correlated biochemical properties were ethylene production, titratable acidity, and soluble solid content and the following pectinolytic enzyme activities: PG, PME, $\beta$ $\mathrm{Gal}$, and $\alpha$-Arab.

\section{Materials and Methods}

\section{Samples}

We used previous information to choose four apricot cultivars with different behaviors under cooking conditions: Goldrich, Hargrand, Iranien, and Orangered. The apricots were obtained from an INRA orchard in l'Amarine (Bellegarde, France) in 2014. Two ripening stages were considered according to the whole firmness of the fruit: commercial harvest (M1) and halfripe (M2). The whole firmness, including skin resistance and flesh firmness, was measured by a compression test (Penelaup multipurpose texturometer, Serisud, Montpellier, France) as the force required to compress $3 \%$ of the equatorial height of the fruit. Homogeneous sample lots were obtained by measuring the whole firmness of at least 230 fruits per cultivar. Apricots' whole firmness was $125-135 \mathrm{kPa}$ for M1 and 97 $99 \mathrm{kPa}$ for M2.

Four zones were defined in the fruit flesh (mesocarp) to evaluate the intra-fruit heterogeneity of texture (by puncture test): external equatorial (EE), median equatorial (ME), external pistil (EP), and median pistil (MP) (Fig. 1). The peduncle, the internal equatorial, and the internal pistil zones were not evaluated due to their lower representation of firmness changes in apricot after cooking (Ella Missang et al. 2011). The biochemical properties (soluble solids, titratable acidity, and pectinolytic enzyme activities) were evaluated in the zones mentioned previously, in addition to the peduncle zone $(\mathrm{P})$, which was included to give a whole characterization of these properties along the longitudinal axis of the fruit (Fig. 1).

Ripening stage determination, ethylene production, pasteurization, and texture determinations were performed at the day of harvest, as were samplings for soluble solids, titratable acidity, and pectinolytic activities. For the latter, samples were 


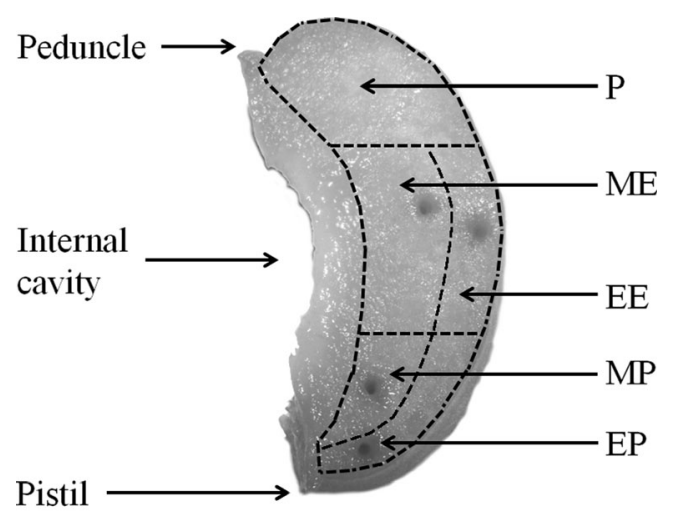

Fig. 1 Apricot slice showing the intra-fruit zones included in the experimentation and the penetration points of the puncture test. $P$ peduncle, $E E$ external equatorial, $M E$ median equatorial, $E P$ external pistil, $M P$ median pistil

cut in small pieces, plunged in liquid nitrogen, and kept at $-80{ }^{\circ} \mathrm{C}$ until analysis.

\section{Real-Time Creep Test}

Creep experiments were performed on notched slices $(2.5 \mathrm{~mm}$ thick) from $\mathrm{M} 1$ apricots during $10 \mathrm{~min}$ with a miniature tensile stage equipped with a $2 \mathrm{~N}$ full scale cell (DB-T200 Petri, Deben Microtest, Woolpit, UK). The slices were glued at both ends on two moving arms of the tensile stage. Measurements were performed in a double-jacketed glass vessel with $16^{\circ} \mathrm{Bx}$ cane sugar syrup, under noncooking conditions $\left(23^{\circ} \mathrm{C}\right)$ and cooking conditions $\left(80^{\circ} \mathrm{C}\right)$. The resistance to traction was determined by the tissue extension during temperature rise under constant load $(0.1 \mathrm{~N})$. The data were modeled with a three-parameter Burger's equation A minimum of three tests was performed per cultivar at each temperature.

\section{Pasteurization}

The apricots were cooked in glass jars simulating the industrial canning of apricots. Unpeeled halves were plunged in $16^{\circ} \mathrm{Bx}$ cane sugar syrup at $70^{\circ} \mathrm{C}$, then heated until center of the apricot halves reached of $85^{\circ} \mathrm{C}$, and cooled immediately after on ice water.

\section{Kramer Shear Test}

Firmness of pasteurized apricots was determined by the Kramer shear test using a multipurpose texture analyzer (TAPlus, Lloyd Instruments, Fareham, UK) equipped with a $1000 \mathrm{~N}$ load cell. The Kramer cell operated at a rate of $20 \mathrm{~cm} \mathrm{~min}^{-1}$. The results were obtained from three replicates of approximately $100 \mathrm{~g}$ of cooked halves from different apricots, and the results were expressed as the maximum force $(\mathrm{N})$ standardized for $100 \mathrm{~g}$ of sample. The amount of sample and the orientation of the halves in the cell were kept constant between replicates in order to minimize variation between analyses.

\section{Puncture Test}

The firmness of raw and pasteurized apricots, considering also the fruit zones (Fig. 1), was determined with a multipurpose texture analyzer (TAPlus), equipped with a $50 \mathrm{~N}$ load cell and a flat tip cylindrical probe with a diameter of $2.0 \mathrm{~mm}$. Tests were performed on 15-mm-thick slices, cut with parallel surfaces along the longitudinal fruit axis. The penetration was performed at a rate of $100 \mathrm{~mm} \mathrm{~min}^{-1}$ up to a depth of $9 \mathrm{~mm}$. Firmness was calculated as the mean of the maximum force (N) used on the penetration of 12 (raw) or 10 (pasteurized) fruit slices. Firmness loss (\%) was calculated between raw (initial firmness, $0 \%$ firmness loss) and pasteurized fruit.

\section{Ethylene Production}

A set of four intact apricots was confined in a jar, and its ethylene production was analyzed $1 \mathrm{~h}$ later by gas chromatography coupled to flame ionization detector (Gouble et al. 2012). The measurements were performed in triplicate with three different sets of apricots per cultivar and ripening stage. The results were adjusted to the weight of the apricot set.

\section{Soluble Solid Content and Titratable Acidity}

Both were estimated by the destructive optical method based on mid-infrared spectroscopy described by Bureau et al. (2009) and implemented using an apricot database from 2005 to 2012. Each experimental condition (cultivar, ripening stage, and intra-fruit zone, $n=40$ ) had two replicates, and each replicate was obtained from homogenized pools of 12 apricots. Frozen samples were finely ground in liquid nitrogen (A11 basic analytical mill, Ika, Staufen, Germany), thawed at room temperature, and analyzed in a Tensor 27 spectrometer FT-MIR spectrometer equipped with a deuterated triglycine sulfate (DTGS) detector and a horizontal attenuated total reflectance (ATR) accessory composed of a zinc selenide (ZnSe) crystal with six internal reflections (Bruker Optics, Wissembourg, France). The reference spectra were recorded using a blank ATR crystal. Fruit purees were then put on the $\mathrm{ZnSe}$ crystal for measurements.

\section{Enzyme Extractions and Assays}

Each experimental condition (cultivar, ripening stage, and intra-fruit zone, $n=40$ ) had two replicates, and each replicate was obtained from homogenized pools of 12 apricots. One sample per replicate was extracted and analyzed for enzyme activities. Frozen samples were finely ground in liquid 
nitrogen and extracted according to the different pectinolytic activities.

PG activities were determined by the method of Gross (1982) with some modifications. Apricot powder $(0.5 \mathrm{~g})$ was mixed with $1 \mathrm{~mL} 10.5 \mathrm{mmol} \mathrm{L}^{-1} \mathrm{Na}_{2} \mathrm{~S}_{2} \mathrm{O}_{5}$ and centrifuged ( $2 \mathrm{~min}, 16,000 \times \mathrm{g}$ ) in order to remove sugars and other soluble interfering substances. After rinsing twice, the pellet was added

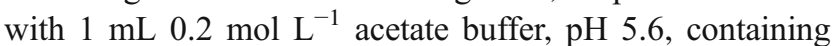
$1 \mathrm{~mol} \mathrm{~L}^{-1} \mathrm{NaCl}$ and $10 \mathrm{~g} \mathrm{~L}^{-1}$ polyvinylpolypyrrolidone (PVPP, Sigma-Aldrich, Saint-Quentin-Fallavier, France); the mixture was stirred for $1 \mathrm{~h}$ at $4{ }^{\circ} \mathrm{C}$ and centrifuged for $30 \mathrm{~min}$ at $16,000 \times g$ and $4{ }^{\circ} \mathrm{C}$ to extract PG (clear supernatant). An aliquot of the crude extracts was added to $0.05 \mathrm{~mol} \mathrm{~L}^{-1}$ acetate buffer, $\mathrm{pH}$ 5.0, containing $3 \mathrm{~g} \mathrm{~L}^{-1}$ pectate and $100 \mathrm{mg} \mathrm{L}^{-1}$ $\mathrm{NaN}_{3}$ and incubated at $35{ }^{\circ} \mathrm{C}$ with stirring (Thermomixer F, Eppendorf, Montesson, France). The pectate was obtained by alkaline demethylation from apple pectin (Sigma-Aldrich) as described by Renard and Jarvis (1999). At several incubation times, $100 \mu \mathrm{L}$ of the reaction solution and $100 \mu \mathrm{L}$ of $10 \mathrm{~g} \mathrm{~L}^{-1}$ 2-cyanoacetamide (Sigma-Aldrich) were added to $500 \mu \mathrm{L}$ of $0.1 \mathrm{~mol} \mathrm{~L}^{-1}$ borate buffer, $\mathrm{pH} 9.0$, boiled for $10 \mathrm{~min}$, and cooled before reading at $276 \mathrm{~nm}$ (FLX-Xenius, Safas, Monaco). The released reducing ends were quantified by calibration with a monogalacturonic acid standard curve at $0.06-1.2-\mathrm{mM}$ range (Sigma-Aldrich). The production rate of reducing ends, at pH 5.0 and $35^{\circ} \mathrm{C}$, was used to define the PG activity.

An adaptation of the method of Houben et al. (2014) was used to determine the PME activity. PME was extracted from $0.5 \mathrm{~g}$ of samples with $1 \mathrm{~mL} 0.2 \mathrm{~mol} \mathrm{~L}^{-1}$ phosphate buffer, $\mathrm{pH} 7.0$, containing $1 \mathrm{~mol} \mathrm{~L}^{-1} \mathrm{NaCl}$. The mixture was stirred for $2 \mathrm{~h}$ at $4{ }^{\circ} \mathrm{C}$ and centrifuged for $30 \mathrm{~min}$ at $16,000 \times g$ and $4{ }^{\circ} \mathrm{C}$ to obtain the PME crude extract (clear supernatant). An aliquot of the extract $(250 \mu \mathrm{L})$ was added to $3.5 \mathrm{~g} \mathrm{~L}^{-1}$ apple pectin solution (70-75\% esterification, Sigma-Aldrich), in $0.12 \mathrm{~mol} \mathrm{~L}^{-1} \mathrm{NaCl}$. The mixture was kept for $30 \mathrm{~min}$ at $\mathrm{pH} 7.0$ and $35^{\circ} \mathrm{C}$ under stirring in an automatic $\mathrm{pH}$ titrator (Metrohm, Herisau, Switzerland); carboxylic groups liberated by de-esterification of the pectin methyl groups were measured by titration with $0.1 \mathrm{~mol} \mathrm{~L}^{-1} \mathrm{NaOH}$. The amount of carboxylic groups liberated at $\mathrm{pH} 7.0$ and $35^{\circ} \mathrm{C}$ was used to define the PME activity.

$\beta$-Gal and $\alpha$-Arab activities were measured as described by Houben et al. (2013) with some modifications. The glycosidases were extracted from $0.5 \mathrm{~g}$ of samples with $1 \mathrm{~mL}$ $0.1 \mathrm{~mol} \mathrm{~L}^{-1}$ borate buffer, $\mathrm{pH} 9.0$, containing $1.2 \mathrm{~mol} \mathrm{~L}^{-1}$ $\mathrm{NaCl}, 10 \mathrm{~mL} \mathrm{~L}^{-1}$ Triton X-100, and $10 \mathrm{~g} \mathrm{~L}^{-1}$ PVPP. The mixture was stirred for $2 \mathrm{~h}$ at $4{ }^{\circ} \mathrm{C}$ and centrifuged for $30 \mathrm{~min}$ at $16,000 \times g$ and $4{ }^{\circ} \mathrm{C}$ to extract the glycosidases (clear supernatant). The incubations were performed in a microplate spectrophotometer (FLX-Xenius, Safas), at $37^{\circ} \mathrm{C}$ for $60 \mathrm{~min}$. We used $1 \mathrm{mmol} \mathrm{L}{ }^{-1} p$-nitrophenyl- $\beta$-D-galactopyranoside or $1 \mathrm{mmol} \mathrm{L}^{-1} p$-nitrophenyl- $\alpha$-L-arabinofuranoside (SigmaAldrich) in $50 \mathrm{mmol} \mathrm{L}^{-1}$ citrate buffer ( $\mathrm{pH} \mathrm{4.4)}$ as substrates for $\beta$-Gal and $\alpha$-Arab, respectively. An aliquot of the extracts $(10 \mu \mathrm{L})$ was added to $190 \mu \mathrm{L}$ of substrate, and the absorbance was recorded at $400 \mathrm{~nm}$ every $1 \mathrm{~min}$ to measure the liberation of nitrophenol. The rate of nitrophenol release from the glycosides, at $\mathrm{pH} 4.4$ and $37^{\circ} \mathrm{C}$, was used to define the glycosidase activities. Its quantification was performed using a $p$-nitrophenol standard curve at 0.4-1.6-mM range (Sigma-Aldrich).

\section{Statistical Analysis}

Effects of cultivar, ripening stage, and intra-fruit zone on texture and biochemical variables were tested for statistical significance by a multifactor ANOVA with all factors and twoway interactions taken into account. Differences between means were assessed by the Tukey HSD test, at the level of significance $\alpha=0.05$. Correlations between firmness and biochemical variables were determined by principal component analysis (PCA) and Pearson's correlation coefficients (Xlstat 2014, Addinsoft, Paris, France).

\section{Results and Discussion}

\section{Ethylene Production}

The cultivars could be divided into two groups concerning their ethylene production at the ripening stages M1 and M2: Goldrich, on the one hand, as a higher producer of ethylene, and Hargrand, Iranien, and Orangered on the other hand (Fig. 2). The effect of ripening stage was not significant for each cultivar separately, but taken together, it had a significant effect (Table 1), with higher production of ethylene at M2 than M1. The effect of ripening was similar in all cultivars, as evidenced by the nonsignificant interaction between these two factors (Table 1).

The production of ethylene in fruit is very relevant in terms of texture, given that this plant hormone triggers many of the physiological and biochemical changes in plants that bring fruit to the maturation and senescence (Bennett and Labavitch 2008). This is in agreement with the effect of ripening observed here, with an increased tendency to the production of hormone with maturation. We could expect higher production rates to all the cultivars at the subsequent ripening stages.

\section{Soluble Solid Content}

Soluble solid content (SSC) is a major parameter affecting fruit quality, as sugars and organic acids are major contributors to SSC. Differences in SSC were found according to the cultivar: Iranien was the richest, followed by Orangered, Hargrand, and Goldrich. Logically, apricots accumulated soluble solids with ripening. Concerning the effect of intra-fruit zone, we observed a clear and significant trend of 

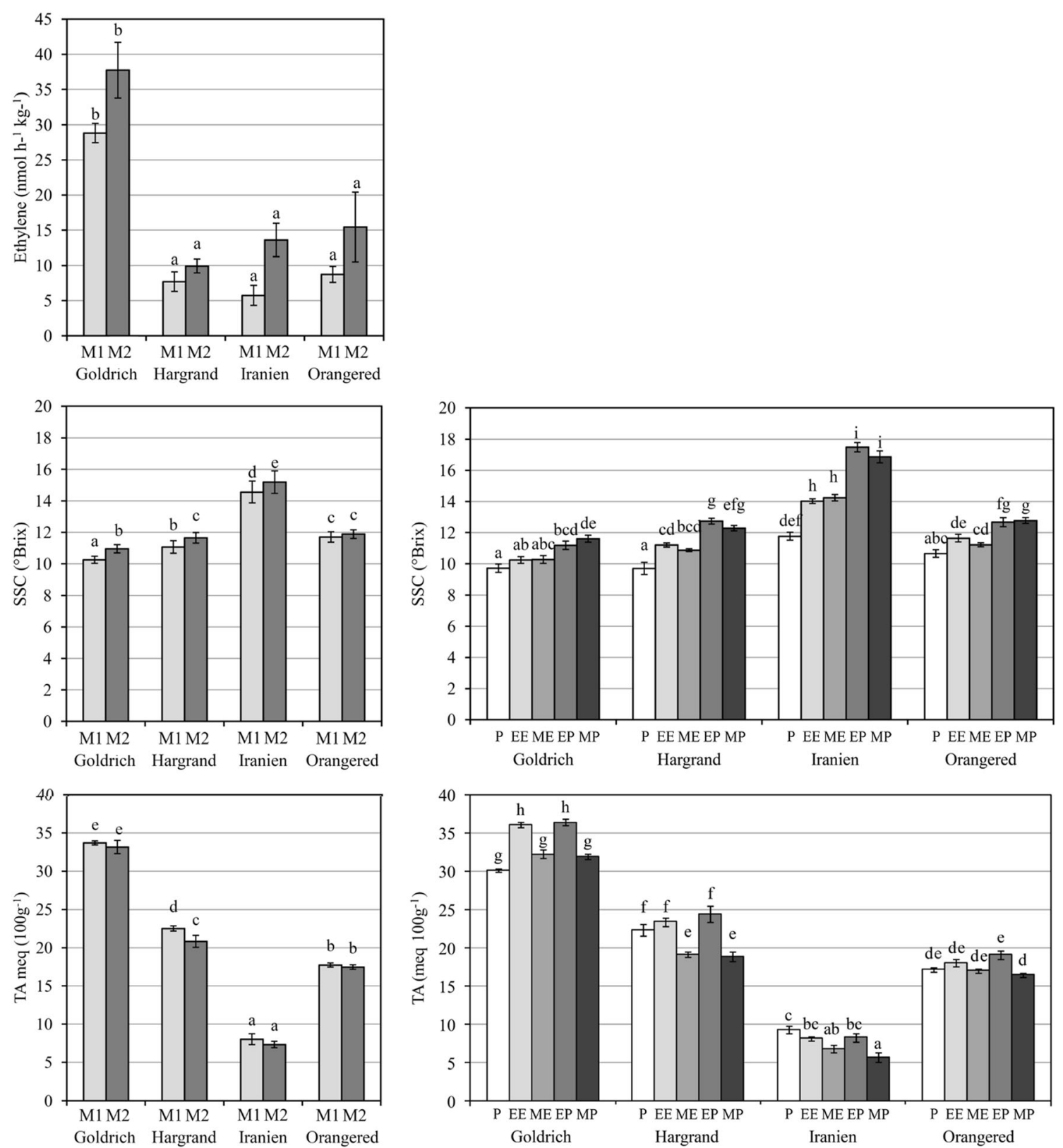

Fig. 2 Ethylene production rates, soluble solid content (SSC), and titratable acidity (TA) in raw apricots according to cultivar and ripening stage (left) and cultivar and intra-fruit zone (right). M1 commercial harvest, $M 2$ half-ripe, $P$ peduncle, $E E$ external equatorial, $M E$ median

equatorial, $E P$ external pistil, $M P$ median pistil. Error bars show standard error (ethylene chart $n=3$, other left-hand charts $n=10$, right-hand charts $n=4)$. Different letters indicate significant differences between means (Tukey HSD, $\alpha=0.05$ )

accumulation along the longitudinal axis, i.e., increasing SSC from peduncle to pistil zones, in all four cultivars (Fig. 2). Cultivar, ripening stage, and intra-fruit zone were significant factors affecting SSC, according to the ANOVA analysis (Table 1).

\section{Titratable Acidity}

Acidity is a very important trait for fruit quality and the consumer's acceptability. For the tested cultivars, titratable acidity (TA) and SSC were inversely correlated. Goldrich had the highest TA, followed by Hargrand, Orangered, and Iranien. The differences between cultivars were remarkable: the average of TA in Goldrich was four times higher than in Iranien (Fig. 2). Lower effect was found for the ripening stage, showing a decrease in TA with the maturation, although it was only significant for Hargrand. The different distribution pattern according to the intra-fruit zones was different from that observed for SSC. The accumulation of organic acids followed the transversal axis; i.e., the TA increased from the median to the external mesocarp (Fig. 2). Again, cultivar, ripening stage, and intra-fruit zone had a significant effect (Table 1). 
Table 1 Statistical significance of cultivar, ripening stage, and intra-fruit zone on raw apricot biochemical properties (ANOVA $p$ values)

\begin{tabular}{|c|c|c|c|c|c|c|c|}
\hline Factor & Ethylene & SSC & TA & PG & PME & $\beta-G a l$ & $\alpha$-Arab \\
\hline Cultivar & $<0.0001 *$ & $<0.0001^{*}$ & $<0.0001^{*}$ & $0.001 *$ & $<0.0001^{*}$ & $<0.0001 *$ & $<0.0001^{*}$ \\
\hline Ripening stage & $0.003 *$ & $<0.0001^{*}$ & $0.000^{*}$ & 0.199 & $<0.0001 *$ & $<0.0001^{*}$ & $<0.0001 *$ \\
\hline Intra-fruit zone & - & $<0.0001^{*}$ & $<0.0001^{*}$ & 0.133 & $<0.0001^{*}$ & $<0.0001^{*}$ & $<0.0001 *$ \\
\hline Cultivar $\times$ ripening stage & 0.599 & 0.115 & 0.076 & $<0.0001 *$ & 0.477 & $0.001 *$ & $0.006^{*}$ \\
\hline Cultivar $\times$ intra-fruit zone & - & $<0.0001^{*}$ & $<0.0001^{*}$ & $0.007 *$ & $<0.0001 *$ & $<0.0001^{*}$ & $0.002 *$ \\
\hline
\end{tabular}

SSC soluble solid content, TA titratable acidity, $P G$ polygalacturonase activity, $P M E$ pectinmethylesterase activity, $\beta$-Gal $\beta$-galactosidase activity, $\alpha$ Arab $\alpha$-arabinosidase activity

*Significant value $(\alpha=0.05)$

\section{Polygalacturonase Activity}

Some differences in PG activity could be observed between cultivars. The largest difference was found between Iranien and Orangered at M1 (Fig. 3). For all cultivars together, no significant effects of ripening stage or intra-fruit zone were found (Table 1). However, the significant interaction cultivar $\times$ ripening stage results from the significant decrease of PG activity with ripening in Orangered (Fig. 3), contrary to the other cultivars. PG activities in all apricots were relatively low compared to some other fruit and vegetables (Pressey 1988; Nunes et al. 2008; Gwanpua et al. 2014). However, Cardarelli et al. (2002) found no detectable PG activity in apricots.

\section{Pectinmethylesterase Activity}

PME activities varied considerably according to the cultivar (Fig. 3). Hargrand had the highest values, followed by Orangered, Iranien, and Goldrich. The activity tended to decrease with ripening, especially in Iranien, where this decrease was significant. An important effect of intra-fruit zone was also observed, and this effect was clearly influenced by the cultivar, as signaled by the significant interaction cultivar $\times$ intra-fruit zone (Table 1). Goldrich and Orangered apricots showed homogeneous PME activities across the different mesocarp zones. Iranien, on the other hand, showed a zonal heterogeneity along the longitudinal axis of the fruit, from lower activity at the peduncle to higher activity at the pistil. Hargrand also showed zonal heterogeneity, but in this case, the highest differences were along the transversal axis, from higher activity at the external zones to lower activity at the median zones. These results highlight the importance of cultivar to explain PME activity in apricot. Even higher activities were reported in other apricot cultivars (Cardarelli et al. 2002; Botondi et al. 2003).

\section{$\beta$-Galactosidase Activity}

Important effects were found for cultivar, ripening stage, and intra-fruit zone on $\beta$-Gal activity (Table 1, Fig. 3). Goldrich and Orangered had the highest $\beta$-Gal activity, followed by Hargrand and Iranien. An increasing trend was observed with ripening, more pronounced in Hargrand and Orangered. The effect of the intra-fruit zone was different concerning the different cultivars: Orangered had a clear tendency to increased $\beta$-Gal activity from peduncle to pistil zones, along the longitudinal axis of the fruit. The rest of the cultivars, even though showing a certain decreasing trend from the external to the internal zones, had no significant differences across the intra-fruit zones. The statistical analysis found significant effects for all the tested factors and interactions (Table 1). Lower $\beta$-Gal activities have been reported in other cultivars (Cardarelli et al. 2002; Botondi et al. 2003).

\section{$\alpha$-Arabinosidase Activity}

Results of $\alpha$-Arab were similar to those for $\beta$-Gal, indicating that the regulation of these two enzymes must be closely related in apricot (Fig. 3). As reported for $\beta$-Gal, Goldrich and Orangered showed the highest $\alpha$-Arab activities, followed by Hargrand and Iranien. The $\alpha$-Arab activity increased significantly in Hargrand and Orangered with maturation. The same cultivars had increasing $\alpha$-Arab activities from peduncle to pistil zones. The statistical analysis showed that cultivar, ripening stage, intra-fruit zone, and their interactions had significant effects (Table 1).

We found relatively high values for $\alpha$-Arab activities in apricots, slightly below the $\beta$-Gal values. This is in contrast

Fig. 3 Polygalacturonase (PG), pectinmethylesterase (PME), $\beta$ galactosidase $(\beta-\mathrm{Gal})$, and $\alpha$-arabinosidase $(\alpha$-Arab) activities in raw apricots according to cultivar and ripening stage (left) and cultivar and intra-fruit zone (right). $M 1$ commercial harvest, $M 2$ half-ripe, $P$ peduncle, $E E$ external equatorial, $M E$ median equatorial, $E P$ external pistil, $M P$ median pistil. Error bars show standard error (left-hand charts $n=10$, right-hand charts $n=4)$. Different letters indicate significant differences between means (Tukey HSD, $\alpha=0.05$ ) 

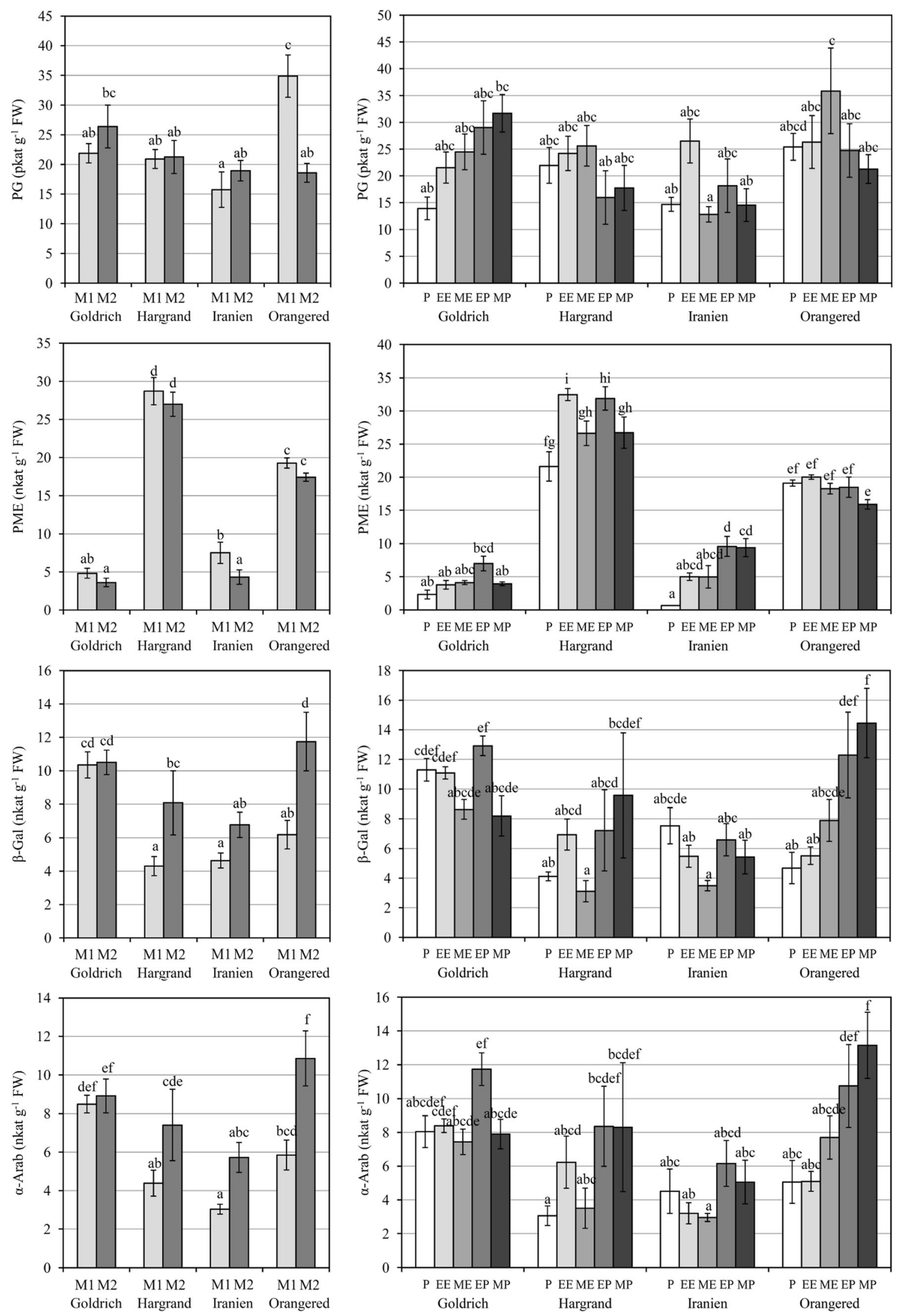


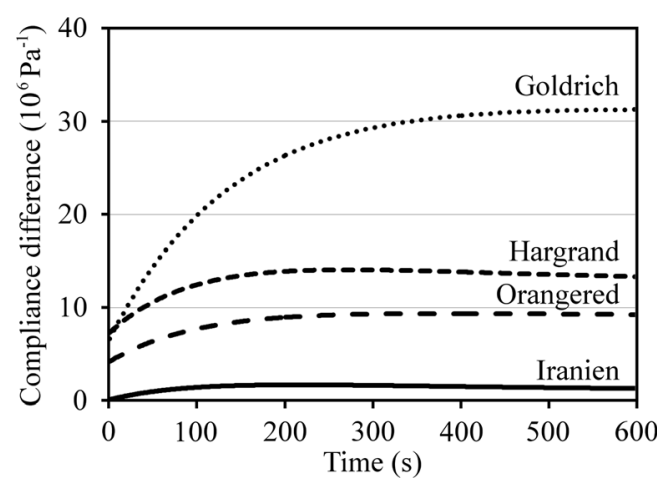

Fig. 4 Kinetics of the compliance difference between 80 and $23{ }^{\circ} \mathrm{C}$ of apricot tissue immersed in syrup $(n=3)$

to what has been reported in other fruit and vegetables, where the ratio $\beta$-Gal/ $\alpha$-Arab is high (Houben et al. 2013; Gwanpua et al. 2014). However, it is in agreement with Cardarelli et al. (2002) who also studied apricots. Other glycosidases, not as much involved in texture changes, were also present at high levels (data not shown). This, which is in agreement with previous results in apricot (Cardarelli et al. 2002; Botondi et al. 2003), might be consequence of an important participation of glycosidases in the apricot metabolism.

\section{Effect of Cooking on Apricot Texture: Real-Time Creep Test}

The real-time creep test allowed modeling the mechanical resistance of the apricot tissue to the traction under noncooking $\left(23^{\circ} \mathrm{C}\right)$ and cooking conditions $\left(80^{\circ} \mathrm{C}\right)$ over time. At $23^{\circ} \mathrm{C}$, Orangered

Table 2 Firmness of pasteurized apricots as a function of cultivar and ripening stage (Kramer shear test maximum force, mean $\pm \mathrm{SD}$ )

\begin{tabular}{llll}
\hline Factor & ANOVA $p$ & Level & Firmness $\left(\mathrm{N} 100 \mathrm{~g}^{-1}\right)$ \\
\hline Cultivar $(n=6)$ & \multirow{2}{*}{$<0.0001^{*}$} & Goldrich & $82 \pm 11 \mathrm{a}$ \\
& & Hargrand & $298 \pm 36 \mathrm{~b}$ \\
& & Iranien & $504 \pm 90 \mathrm{c}$ \\
& & Orangered & $488 \pm 104 \mathrm{c}$ \\
Ripening stage & \multirow{2}{*}{0.069} & M1 & $366 \pm 202 \mathrm{a}$ \\
$(n=12)$ & & M2 & $320 \pm 177 \mathrm{a}$ \\
Cultivar $\times$ ripening & \multirow{2}{*}{$0.034^{*}$} & Goldrich M1 & $78 \pm 13 \mathrm{a}$ \\
stage $(n=3)$ & & Goldrich M2 & $87 \pm 8 \mathrm{a}$ \\
& & Hargrand M1 & $319 \pm 34 \mathrm{~b}$ \\
& & Hargrand M2 & $276 \pm 27 \mathrm{~b}$ \\
& & Iranien M1 & $492 \pm 48 \mathrm{~cd}$ \\
& & Iranien M2 & $517 \pm 132 \mathrm{~cd}$ \\
& & Orangered M1 & $575 \pm 53 \mathrm{~d}$ \\
& & Orangered M2 & $401 \pm 42 \mathrm{bc}$ \\
\hline
\end{tabular}

Different letters at the same factor indicate significant differences between levels (Tukey HSD, $\alpha=0.05$ )

$M 1$ commercial harvest, $M 2$ half-ripe

* Significant $p$ values $(\alpha=0.05)$
Table 3 Firmness loss in pasteurized apricots as function of cultivar, ripening stage, and intra-fruit zone (puncture test, percentage of firmness loss as measured by the maximum force, mean \pm SD)

\begin{tabular}{|c|c|c|c|}
\hline Factor & ANOVA $p$ & Level & $\begin{array}{l}\text { Initial firmness } \\
\text { loss }(\%)\end{array}$ \\
\hline \multirow[t]{4}{*}{ Cultivar $(n=8)$} & \multirow[t]{4}{*}{$<0.0001 *$} & Goldrich & $86 \pm 2 \mathrm{c}$ \\
\hline & & Hargrand & $74 \pm 7 b$ \\
\hline & & Iranien & $75 \pm 3 b$ \\
\hline & & Orangered & $67 \pm 9 \mathrm{a}$ \\
\hline \multirow[t]{2}{*}{ Ripening stage $(n=16)$} & \multirow[t]{2}{*}{$0.012 *$} & M1 & $74 \pm 10 \mathrm{a}$ \\
\hline & & M2 & $78 \pm 7 b$ \\
\hline \multirow[t]{4}{*}{ Intra-fruit zone $(n=8)$} & \multirow[t]{4}{*}{0.071} & $\mathrm{EE}$ & $77 \pm 10 \mathrm{a}$ \\
\hline & & $\mathrm{ME}$ & $74 \pm 11 \mathrm{a}$ \\
\hline & & EP & $78 \pm 8 \mathrm{a}$ \\
\hline & & MP & $74 \pm 8 \mathrm{a}$ \\
\hline \multirow{8}{*}{$\begin{array}{l}\text { Cultivar } \times \text { ripening } \\
\text { stage }(n=4)\end{array}$} & \multirow[t]{8}{*}{$0.005^{*}$} & Goldrich M1 & $86 \pm 2 \mathrm{~cd}$ \\
\hline & & Goldrich M2 & $86 \pm 2 d$ \\
\hline & & Hargrand M1 & $74 \pm 6 b$ \\
\hline & & Hargrand M2 & $74 \pm 9 b$ \\
\hline & & Iranien M1 & $75 \pm 1 b$ \\
\hline & & Iranien M2 & $76 \pm 5 \mathrm{bc}$ \\
\hline & & Orangered M1 & $59 \pm 5 \mathrm{a}$ \\
\hline & & Orangered M2 & $75 \pm 4 b$ \\
\hline \multirow{16}{*}{$\begin{array}{l}\text { Cultivar } \times \text { intra-fruit } \\
\text { zone }(n=2)\end{array}$} & \multirow[t]{16}{*}{0.144} & Goldrich EE & $87 \pm 1 \mathrm{c}$ \\
\hline & & Goldrich ME & $85 \pm 0 \mathrm{bc}$ \\
\hline & & Goldrich EP & $86 \pm 3 \mathrm{c}$ \\
\hline & & Goldrich MP & $86 \pm 3 c$ \\
\hline & & Hargrand EE & $80 \pm 3 a b c$ \\
\hline & & Hargrand ME & $66 \pm 2 \mathrm{a}$ \\
\hline & & Hargrand EP & $82 \pm 1 \mathrm{abc}$ \\
\hline & & Hargrand MP & $69 \pm 2 \mathrm{ab}$ \\
\hline & & Iranien EE & $75 \pm 2 \mathrm{abc}$ \\
\hline & & Iranien $\mathrm{ME}$ & $77 \pm 1 \mathrm{abc}$ \\
\hline & & Iranien EP & $77 \pm 2 \mathrm{abc}$ \\
\hline & & Iranien MP & $72 \pm 5 \mathrm{abc}$ \\
\hline & & Orangered EE & $66 \pm 14 \mathrm{a}$ \\
\hline & & Orangered ME & $67 \pm 18 \mathrm{a}$ \\
\hline & & Orangered EP & $68 \pm 5 \mathrm{a}$ \\
\hline & & Orangered MP & $67 \pm 7 \mathrm{a}$ \\
\hline
\end{tabular}

Different letters at the same factor indicate significant differences between levels (Tukey HSD, $\alpha=0.05$ )

$M 1$ commercial harvest, $M 2$ half-ripe, $E E$ external equatorial, $M E$ median equatorial, $E P$ external pistil, $M P$ median pistil

*Significant $p$ values $(\alpha=0.05)$

and Iranien showed about twice the elasticity of Goldrich and Hargrand, whose retarded elastic moduli (Young's modulus, $E_{2}$ ) were $0.397 \pm 0.150,0.390 \pm 0.046,0.110 \pm 0.044$, and $0.162 \pm 0.002 \mathrm{MPa}$ at the retardation times $250 \pm 54,237 \pm 96$, $279 \pm 100$, and $265 \pm 95 \mathrm{~s}$ (mean $\pm \mathrm{SD}$, for Orangered, Iranien, Goldrich, and Hargrand, respectively). The cooking conditions 
Table 4 Pearson's correlation coefficients between firmness of pasteurized apricots (Kramer shear test) and biochemical indicators of raw fruits

\begin{tabular}{|c|c|c|c|c|c|c|c|c|}
\hline & \multirow{2}{*}{$\begin{array}{l}\text { Texture } \\
\text { Kramer }\end{array}$} & \multicolumn{7}{|c|}{ Biochemical indicators } \\
\hline & & Ethylene & SSC & TA & PG & PME & $\beta-G a l$ & $\alpha-A r a b$ \\
\hline Kramer & 1 & & & & & & & \\
\hline Ethylene & $-0.798 *$ & 1 & & & & & & \\
\hline $\mathrm{SSC}$ & $0.771 *$ & -0.569 & 1 & & & & & \\
\hline TA & $-0.914 *$ & $0.774 *$ & $-0.940 *$ & 1 & & & & \\
\hline PG & 0.415 & -0.501 & 0.215 & -0.289 & 1 & & & \\
\hline PME & 0.148 & -0.562 & -0.243 & -0.028 & 0.098 & 1 & & \\
\hline$\beta-\mathrm{Gal}$ & $-0.955^{*}$ & $0.849^{*}$ & $-0.725 *$ & $0.893 *$ & -0.321 & -0.352 & 1 & \\
\hline$\alpha$-Arab & $-0.918 *$ & $0.724 *$ & $-0.932 *$ & $0.967 *$ & -0.389 & 0.009 & $0.902 *$ & 1 \\
\hline
\end{tabular}

SSC soluble solid content, TA titratable acidity, $P G$ polygalacturonase activity, $P M E$ pectinmethylesterase activity, $\beta$-Gal $\beta$-galactosidase activity, $\alpha$-Arab $\alpha$-arabinosidase activity

*Significant correlation $(\alpha=0.05)$ $\left(80{ }^{\circ} \mathrm{C}\right)$ led to a great texture loss within a few minutes, with a plateau reached in under $200 \mathrm{~s}$ except for Goldrich (500 s). The texture loss varied for the different cultivars. Figure 4 shows the compliance difference between the modeled creep experiments at 23 and $80{ }^{\circ} \mathrm{C}$ for the four cultivars. The tissue elasticity, which can be estimated as the inverse of the compliance difference, fell by $80 \%$ in Goldrich, $47 \%$ in Hargrand, $40 \%$ in Orangered, and 30\% in Iranien after 10 min (Fig. 4).

\section{Effect of Pasteurization on Apricot Texture: Kramer Shear Test}

The results of the Kramer shear test were similar to those of the creep test: the firmness of the pasteurized fruit was higher in Orangered and Iranien cultivars, followed by Hargrand and Goldrich (Table 2). The latter showed about six times less firmness than Iranien and Orangered after pasteurization. In the ANOVA, cultivar was a strong factor affecting cooked apricot texture. The effect of ripening stage was not significant taking the four cultivars together; however, it was significant in Orangered cultivar, which showed lower firmness for the apricots at the M2 stage.

\section{Effect of Pasteurization on Apricot Texture: Puncture Test}

This third method for texture characterization allowed us to evaluate also the effect of intra-fruit zone on the loss of firmness due to pasteurization, in addition to the effects of cultivar and ripening stage. The loss of firmness was calculated following puncture tests of raw and pasteurized fruit slices. Data were expressed as the percentage of loss of the initial firmness, i.e., the firmness of raw fruit before pasteurization. Orangered was the most resistant to texture loss, with $67 \%$ loss of firmness (Table 3). Hargrand and Iranien lost 74 and 75\%, respectively, while Goldrich, which was the least resistant cultivar, lost $86 \%$. The effect of ripening stage was also significant, with higher decrease of firmness in riper fruit. The most significant decrease due to maturation was observed in Orangered cultivar, in agreement with the Kramer shear test. There was a certain tendency towards higher decrease of firmness at the external tissues, especially in Hargrand cultivar. However, the effect of intra-fruit zone was not significant, according to the ANOVA (Table 3).

\section{Correlations Between Firmness (Kramer Shear Test) and Biochemical Properties}

As all three texture methods gave congruent results, Kramer shear and puncture tests were chosen for further data analysis for a global evaluation. A principal component analysis (PCA) evaluated possible correlations between firmness of pasteurized fruit (as measured by the Kramer shear test), ethylene production, SSC, TA, and pectinolytic enzyme activities. All variables in the PCA included data from cultivars and ripening stages. For SSC, TA, and pectinolytic enzymes, only data from the EE zone were taken into account, given that Kramer and ethylene data could not be acquired concerning the different intra-fruit zones. Very strong negative correlations were found between firmness of pasteurized apricots and $\beta-\mathrm{Gal}, \alpha-\mathrm{Arab}, \mathrm{TA}$, and ethylene production (Table 4). In contrast, SSC was positively correlated with firmness. The significantly correlated variables contributed mostly to the first principal component, which explained $68 \%$ of the variability of the overall data (Fig. 5a). The four cultivars were clearly lined up along this principal component, with Iranien, Orangered, Hargrand, and Goldrich from left to right. The more negative the scores, the higher the firmness and SSC content and the lower the TA, $\alpha$-Arab, $\beta$-Gal activities, and ethylene production. In other words, cultivar determined, to a great extent, the biochemical indicators that correlated with firmness of pasteurized apricots. The good correlation between TA and firmness of pasteurized apricots can be visualized by the fair linear regression between these two parameters (Fig. 6a). 

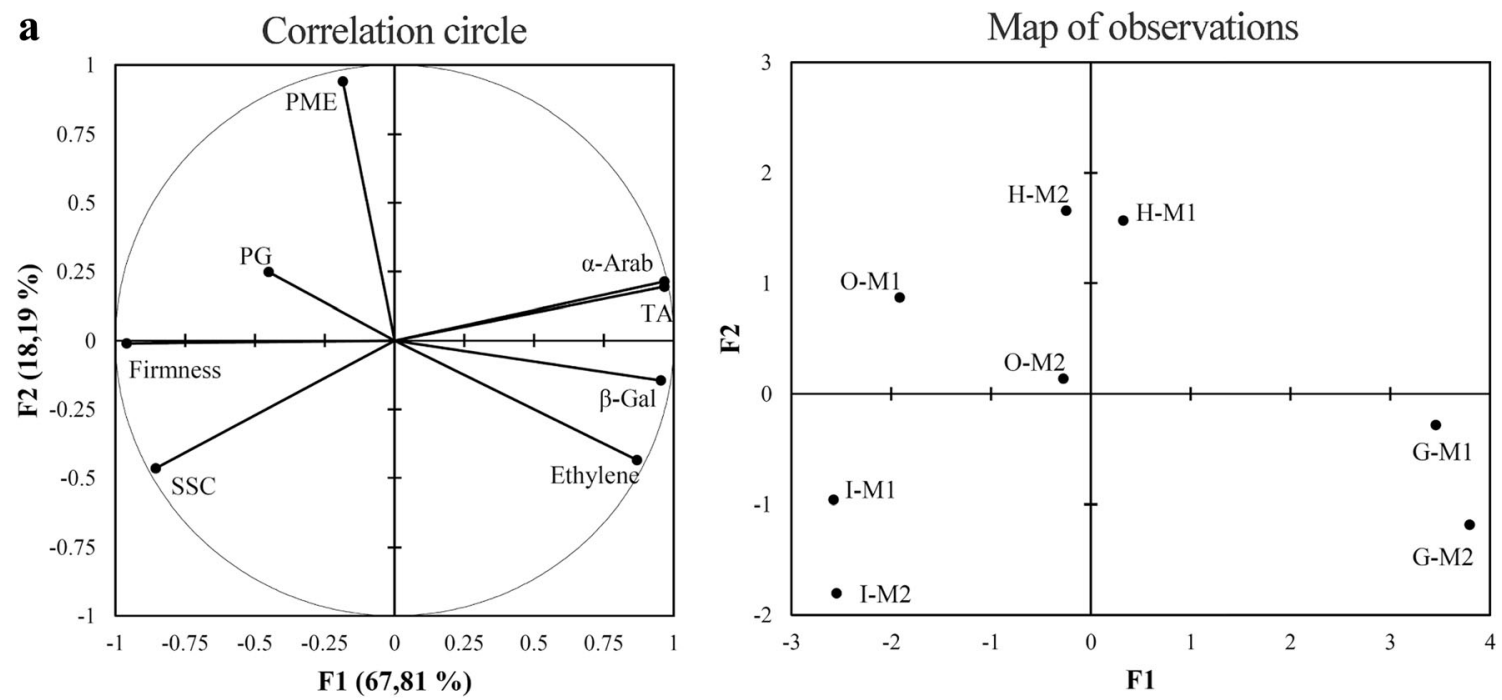

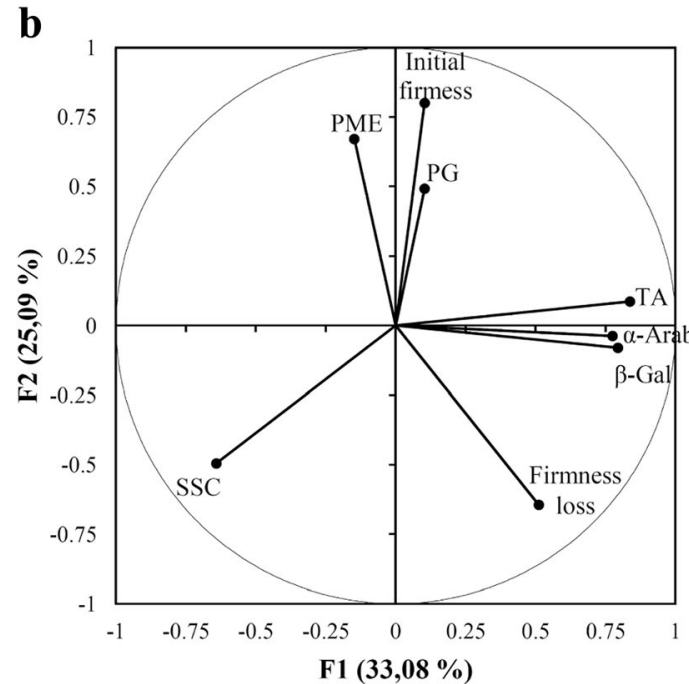

Fig. 5 Principal component analysis showing correlations between apricot firmness and raw fruit biochemical indicators. a Firmness of pasteurized fruit as measured by the Kramer shear test. b Initial firmness and loss of firmness (\%) of apricots before and after pasteurization, as measured by the puncture test. Biochemical indicator abbreviations: $\alpha$-Arab $\alpha$-arabinosidase activity, $\beta$-Gal $\beta$-galactosidase

Some correlations were also observed between biochemical indicators (Table 4). Inverse correlation was found between TA and SSC, and positive correlation between glycosidases ( $\beta$-Gal and $\alpha$-Arab). Glycosidase activities correlated positively with TA, thus negatively with SSC. The plant hormone ethylene correlated positively with glycosidase activities and TA. The latter was clearly due to the Goldrich cultivar, which showed high TA and ethylene production.

\section{Correlations Between Loss of Firmness (Puncture Test), Initial Firmness, and Biochemical Properties}

Firmness data from the puncture test, which included data concerning the cultivar, ripening stage, and intra-fruit zone, both raw and pasteurized, and SSC, TA, and pectinolytic

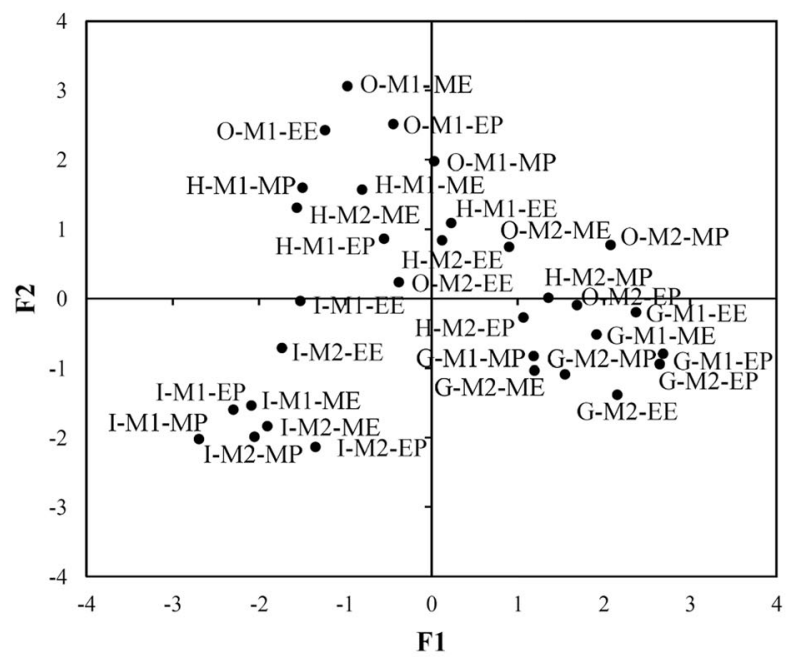

activity, $P G$ polygalacturonase activity, $P M E$ pectinmethylesterase activity, $S S C$ soluble solid content, $T A$ titratable acidity. Cultivar abbreviations: $G$ Goldrich, $H$ Hargrand, $I$ Iranien, $O$ Orangered. Ripeness stage abbreviations: $M 1$ commercial harvest, $M 2$ half-ripe. Intra-fruit zone abbreviations: $E E$ external equatorial, $M E$ median equatorial, $E P$ external pistil, $M P$ median pistil

enzyme activities were also evaluated for significant correlations in a PCA. Three variables correlated significantly with firmness loss: initial firmness and PME activity correlated negatively, while TA, which was the variable with the strongest correlation, correlated positively with firmness loss (Table 5). The loss of texture in pasteurized apricots was more linked to their acidity than their initial texture before treatment or any other biochemical indicator. As for the PCA with Kramer data, data were grouped according to the cultivar on the observation map, while they were apparently not grouped according to the intra-fruit zone (Fig. 5b). Correlations were not tied to the observations of a single cultivar with extreme values. The results are in agreement with Ella Missang et al. (2011), who found a major effect of cultivar and maturation on apricot firmness whereas the 
a

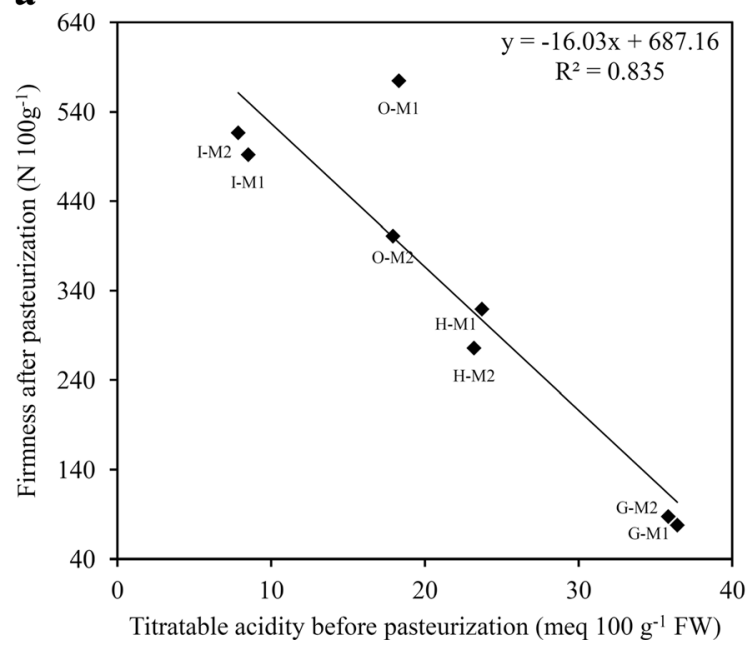

Fig. 6 Linear regressions between firmness of pasteurized apricot and titratable acidity of raw fruit. a Firmness as measured by Kramer test. b Loss of firmness as measured by puncture test. Cultivar abbreviations: $G$ Goldrich, $H$ Hargrand, $I$ Iranien, $O$ Orangered. Ripeness stage

interzone effects were visible on the plane $\mathrm{F} 2 \times \mathrm{F} 3$ of the PCA. The negative link between TA and the texture of pasteurized apricot was roughly supported by the negative trend observed between these two parameters (Fig. 6b).

Besides firmness loss, other correlations were found between the tested biochemical indicators and the initial firmness (Table 5). Firmness of raw apricots was positively correlated with PME activity. As for the PCA with Kramer data, positive correlations were found between $\beta$-Gal and $\alpha$-Arab and between the two glycosidases and TA. Again, a negative correlation was found between TA and SSC. b

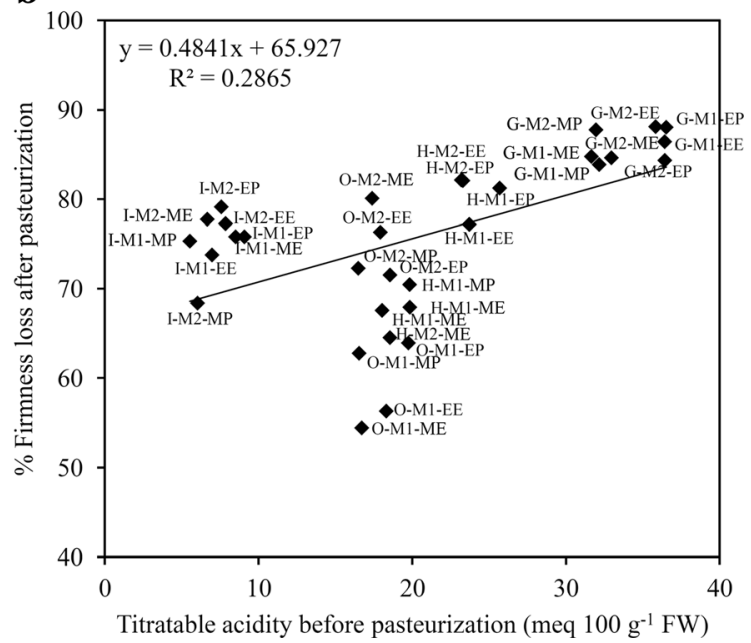

abbreviations: $M 1$ commercial harvest, $M 2$ half-ripe. Intra-fruit zone abbreviations: $E E$ external equatorial, $M E$ median equatorial, $E P$ external pistil, $M P$ median pistil

\section{Conclusions}

Overall results showed, in a first instance, the great complexity of the phenomena that govern the texture modifications in thermally treated apricots. In most cases, the biochemical properties with a potential effect on the apricot texture were highly influenced by cultivar, ripening stage, and intra-fruit zone, and many interactions existed between the effects of these factors. Amongst all, cultivar arose as the factor with higher influence on the biochemical properties. In this study, we used different methodologies to assess the texture evolution of pasteurized apricots, which yielded similar results.

Table 5 Pearson's correlation coefficients between \% firmness loss between pasteurized and raw apricots (as measured by puncture test), firmness of raw apricots, and biochemical indicators of raw fruit

\begin{tabular}{|c|c|c|c|c|c|c|c|c|}
\hline & \multicolumn{2}{|l|}{ Texture } & \multicolumn{6}{|c|}{ Biochemical indicators } \\
\hline & $\%$ Firmness loss & Initial firmness & $\mathrm{SSC}$ & TA & PG & PME & $\beta-\mathrm{Gal}$ & $\alpha$-Arab \\
\hline$\%$ Firmness loss & 1 & & & & & & & \\
\hline Initial firmness & $-0.462 *$ & 1 & & & & & & \\
\hline $\mathrm{SSC}$ & -0.156 & -0.323 & 1 & & & & & \\
\hline TA & $0.535 *$ & -0.013 & $-0.781 *$ & 1 & & & & \\
\hline PG & -0.235 & 0.195 & -0.335 & 0.272 & 1 & & & \\
\hline PME & $-0.394 *$ & $0.406^{*}$ & -0.197 & -0.054 & -0.024 & 1 & & \\
\hline$\beta-\mathrm{Gal}$ & 0.219 & 0.170 & -0.190 & $0.362 *$ & -0.126 & -0.155 & 1 & \\
\hline$\alpha$-Arab & 0.172 & 0.148 & -0.172 & $0.363 *$ & -0.100 & -0.054 & $0.958^{*}$ & 1 \\
\hline
\end{tabular}

SSC soluble solid content, TA titratable acidity, $P G$ polygalacturonase activity, $P M E$ pectinmethylesterase activity, $\beta$-Gal $\beta$-galactosidase activity, $\alpha$ Arab $\alpha$-arabinosidase activity

*Significant correlation $(\alpha=0.05)$ 
Cultivar, again, was the most influent factor influencing texture. Higher TA, ethylene production rates, and glycosidase activities (both $\beta$-Gal and $\alpha$-Arab) of raw apricots had a negative correlation with texture preservation during pasteurization. On the contrary, high firmness, SSC, and PME activity of raw apricots had a positive correlation, depending on the texture methodology employed.

TA was the only biochemical indicator with significant correlation in both texture methodologies. It had very high correlation coefficient with texture at the Kramer test, and it was the indicator with the highest correlation at the puncture test, even higher than the firmness of raw fruit. Therefore, we identify TA as the most robust indicator for texture preservation of pasteurized apricot. The negative impact of the apricot acidity to their texture preservation under pasteurization can be explained in terms of pectin stability. Indeed, pectin stability is paramount to the preservation of texture in fruits, and low $\mathrm{pH}$ of the media may affect its stability to a great extent, facilitating acid hydrolysis. Further studies with more cultivars are needed to confirm this hypothesis.

Acknowledgements This work was financed by the Agence Nationale de la Recherche under the project ILLIAD (ANR-11-ALID-0006). The authors gratefully acknowledge UPPIA and the Prix de Recherche en Nutrition Institut Appert 2014 for economic support.

\section{References}

Bennett, A. B., \& Labavitch, J. M. (2008). Ethylene and ripeningregulated expression and function of fruit cell wall modifying proteins. Plant Science, 175(1-2), 130-136.

Billy, L., Mehinagic, E., Royer, G., Renard, C. M. G. C., Arvisenet, G., Prost, C., et al. (2008). Relationship between texture and pectin composition of two apple cultivars during storage. Postharvest Biology and Technology, 47(3), 315-324.

Botondi, R., DeSantis, D., Bellincontro, A., Vizovitis, K., \& Mencarelli, F. (2003). Influence of ethylene inhibition by 1-methylcyclopropene on apricot quality, volatile production, and glycosidase activity of low- and high-aroma varieties of apricots. Journal of Agricultural and Food Chemistry, 51(5), 1189-1200.

Brummell, D. A., Dal Cin, V., Crisosto, C. H., \& Labavitch, J. M. (2004). Cell wall metabolism during maturation, ripening and senescence of peach fruit. Journal of Experimental Botany, 55(405), 2029-2039.

Bureau, S., Ruiz, D., Reich, M., Gouble, B., Bertrand, D., Audergon, J.M., et al. (2009). Application of ATR-FTIR for a rapid and simultaneous determination of sugars and organic acids in apricot fruit. Food Chemistry, 115(3), 1133-1140.

Cardarelli, M., Botondi, R., Vizovitis, K., \& Mencarelli, F. (2002). Effects of exogenous propylene on softening, glycosidase, and pectinmethylesterase activity during postharvest ripening of apricots. Journal of Agricultural and Food Chemistry, 50(6), 1441-1446.

Chen, Y., Chen, F., Lai, S., Yang, H., Liu, H., Liu, K., et al. (2013). In vitro study of the interaction between pectinase and chelatesoluble pectin in postharvest apricot fruits. European Food Research and Technology, 237(6), 987-993.
Claypool, L. L. (1974). Apricot softening: a problem of the canned fruit. California Agriculture, 28, 4-7.

Diaz, J. V., Anthon, G. E., \& Barrett, D. M. (2007). Nonenzymatic degradation of citrus pectin and pectate during prolonged heating: effects of $\mathrm{pH}$, temperature, and degree of methyl esterification. Journal of Agricultural and Food Chemistry, 55(13), 5131-5136.

Duvetter, T., Sila, D. N., Van Buggenhout, S., Jolie, R., Van Loey, A., \& Hendrickx, M. (2009). Pectins in processed fruit and vegetables: part I-stability and catalytic activity of pectinases. Comprehensive Reviews in Food Science and Food Safety, 8(2), 75-85.

Ella Missang, C., Maingonnat, J. F., Renard, C. M. G. C., \& Audergon, J.M. (2011). Texture variation in apricot: intra-fruit heterogeneity, impact of thinning and relation with the texture after cooking. Food Research International, 44(1), 46-53.

Ella Missang, C., Maingonnat, J. F., Renard, C. M. G. C., \& Audergon, J.M. (2012). Apricot cell wall composition: relation with the intrafruit texture heterogeneity and impact of cooking. Food Chemistry, 133(1), 45-54.

Fraeye, I., De Roeck, A., Duvetter, T., Verlent, I., Hendrickx, M., \& Van Loey, A. (2007). Influence of pectin properties and processing conditions on thermal pectin degradation. Food Chemistry, 105(2), $555-563$.

Gouble, B., Reling, P., Renard, C. M. G. C., \& Audergon, J. M. (2012). Influence of temperature on apricot fruit respiration and ethylene production. Acta Horticulturae, 966, 259-262.

Gross, K. C. (1982). A rapid and sensitive spectrophotometric method for assaying polygalacturonase using 2-cyanoacetamide. Hortscience, 17(6), 933-934.

Gwanpua, S. G., Van Buggenhout, S., Verlinden, B. E., Christiaens, S., Shpigelman, A., Vicent, V., et al. (2014). Pectin modifications and the role of pectin-degrading enzymes during postharvest softening of Jonagold apples. Food Chemistry, 158, 283-291.

Houben, K., Christiaens, S., Ngouémazong, D., Van Buggenhout, S., Van Loey, A., \& Hendrickx, M. (2014). The effect of endogenous pectinases on the consistency of tomato-carrot purée mixes. Food and Bioprocess Technology, 1-11.

Houben, K., Jamsazzadeh Kermani, Z., Van Buggenhout, S., Jolie, R., Van Loey, A., \& Hendrickx, M. (2013). Thermal and high-pressure stability of pectinmethylesterase, polygalacturonase, $\beta$ galactosidase and $\alpha$-arabinofuranosidase in a tomato matrix: towards the creation of specific endogenous enzyme populations through processing. Food and Bioprocess Technology, 6(12), 3368-3380.

Mallidis, C. G., \& Katsaboxakis, C. (2002). Effect of thermal processing on the texture of canned apricots. International Journal of Food Science \& Technology, 37(5), 569-572.

Nunes, C., Saraiva, J. A., \& Coimbra, M. A. (2008). Effect of candying on cell wall polysaccharides of plums (Prunus domestica L.) and influence of cell wall enzymes. Food Chemistry, 111(3), 538-548.

Pressey, R. (1988). Reevaluation of the changes in polygalacturonases in tomatoes during ripening. Planta, 174(1), 39-43.

Renard, C. M. G. C., \& Jarvis, M. C. (1999). Acetylation and methylation of homogalacturonans 1: optimisation of the reaction and characterisation of the products. Carbohydrate Polymers, 39(3), 201-207.

Sommer, N. F., Buchanan, J. R., Fortlage, R. J., \& Mitchell, F. G. (1977). Preventing enzymatic softening of canned apricots. California Agriculture, 31, 16-17.

Van Buggenhout, S., Sila, D. N., Duvetter, T., Van Loey, A., \& Hendrickx, M. (2009). Pectins in processed fruits and vegetables: part III-texture engineering. Comprehensive Reviews in Food Science and Food Safety, 8(2), 105-117.

Van Buren, J. P. (1979). The chemistry of texture in fruits and vegetables. Journal of Texture Studies, 10(1), 1-23. 